\title{
Characterization of a Coronavirus Isolated from Rats with Sialoadenitis
}

\author{
By \\ M. MARU and K. Sato \\ Shionogi Researeh Laboratories, Shionogi \& Co., Ltd., \\ Fukushima-ku, Osaka, Japan
}

With 1 Figure

Accepted March 30, 1982

\begin{abstract}
Summary
A causative agent, provisionally designated as CARS, was isolated from the enlarged submaxillary gland of rat which was characterized as a sialoadenitis, using mouse-derived Balb/c3T3 clone A31 (3T3) cell culture. The virus could be propagated in $3 \mathrm{~T} 3$ cell culture where it produced multinucleated giant cells and formed clear plaques. It was identified as a member of the coronavirus group from the following results: RNA content was suggested by the lack of the effect of cytosine arabinoside, the infectivity was sensitive to lipid solvents and inactivated at $56^{\circ} \mathrm{C}$ for 5 minutes, the viral particle showed typical coronavirus morphology which was approximately $100 \mathrm{~nm}$ in diameter. Serologically, although CARS and sialodacryoadenitis virus (SDAV) actually belonged to the rat-coronavirus group, some antigenic variations existed between these two agents in the results of both neutralization and complement-fixation tests using monovalent antisera. When inoculated intranasally into susceptible rats, CARS caused clinically and histologically overt sialoadenitis as observed in the natural outbreak, and retained its virulence for rats in several passages of mouse brain and even when cell culture was used, while rats which were inoculated with SDAV were asymptomatic.
\end{abstract}

\section{Introduction}

Coronaviruses appear to be important aetiological agents in experimental animals. These viruses are associated with a great variety of diseases $(15,17,19,22)$. For instance, mice infected with mouse hepatitis virus develop hepatitis, encephalitis, chronic immunological mediated diseases $(15,21)$ and diarrhoea $(12)$, and in rats, rhinitis and tracheitis (5), pneumonitis $(5,16)$, sialodacryoadenitis $(13,23)$ and disorder of oesterous cycle $(20)$ were caused by coronaviruses. Two different kinds of coronavirus have been isolated from rats. One is Parker's rat coronavirus (RCV) which causes lethal interstitial pneumonia in newborn rats 
(16), and the other is SDAV isolated from submaxillary glands of naturallyinfected rats showing sialodacryoadenitis (3). An antigenic relationship between these two viruses has been also reported (3).

We encountered an outbreak of contagious disease resembling sialodacryoadenitis of rats (11) in commercially produced rat colonies housed in user's facility, and isolated a virus from the submaxillary glands of affected rats using mouse-derived $3 \mathrm{~T} 3$ cells. The agent, provisionally designated as causative agent of rat sialoadenitis (CARS), was apparently pathogenic for rats, easily propagated in $3 \mathrm{~T} 3$ cells, and exhibited properties of coronavirus group.

This report describes the procedure for isolation, adaptation to $3 \mathrm{~T} 3$ cells and virological characteristics of CARS.

\section{Materials and Methods}

\section{Virus}

SDAV, originally isolated by BHATr et al. (3), and MHV-2 were kindly supplied from Dr. K. Fujiwara, Institute of Medical Science, University of Tokyo, Tokyo, Japan. CARS and MHV-2 were prepared from the supernatant of infected $3 \mathrm{~T} 3$ cell cultures after clarification at $3000 \mathrm{rpm}$ for 15 minutes.

\section{Virus Titration}

To determine the plaque forming-units (PFU), $0.2 \mathrm{ml}$ samples of serial 10 -fold virus dilutions in Hanks' balanced salt solution (HBSS) were inoculated on 3T 3 cell monolayers. After incubation for 1 hour at $37^{\circ} \mathrm{C}$, the monolayers were covered with $5 \mathrm{ml}$ of Eagle's minimum essential medium (MEM) supplemented with 2 per cent of fetal calf serum (maintenance medium) containing 1 per cent Bactoagar (Difco), and incubated. When the plaques appeared, the cultures were covered again with $3 \mathrm{ml}$ of the same overlayer containing 0.002 per cent neutral red and the plaques were counted after 1 day of further incubation.

Titration of CARS to be used for experimental infection of rats was estimated by 50 per cent mouse lethal doses $\left(M L D_{50}\right)$. Two-day-old mice were pooled and assigned randomly, ten babies to one mother. Each group of ten suckling mice was used per dilution and inoculated intracerebrally (i.c.) with approximately $0.02 \mathrm{ml}$ of serial 10 -fold virus dilution/mouse and observed daily for 14 days. Cumulative deaths were recorded.

SDAV used for experiments was prepared from supernatant of emulsion of suckling mice brains which had been infected with the virus after centrifugation at $8000 \mathrm{rpm}$ for 15 minutes, and titrated in 2-day-old nice as described above.

\section{Animals}

Two-day-old suckling mice of the Jel:ICR strain and 8-week-old male rats of the Sle:SD strain were purchased from two different commercial breeders and maintained in a barrier system. Two-day-old suckling mice used for virus isolation were housed in a vinyl isolator, and all bedding, water and diet were steam sterilized. Fight-weekold male rats used for experimental infection were housed in filter-cap cages and reared under conventional conditions.

All these animals were serologically free of MHV.2, Sendai virus and CARS.

\section{Cell Culures}

Mouse-derived $3 \mathrm{~T} 3$ cells were kindly supplied by Dr. K. Kurimura, School of Medicine, University of Tottori, Tottori, Japan. $\mathrm{L}_{929}$, LLCMK $_{2}, \mathrm{CV}-1$ and HeLa cells were maintained in our laboratory with MEM supplemented with 10 per cent fetal calf serum and $100 \mathrm{ug}$ of Kanamycin (growth medium). Primary rat embryo cells (REC) were prepared from 15-day-old whole embryos by trypsinization. Trypsin-dispersed 
embryo cell cultures of mouse (MEC) and chicken (CEC) were also prepared by the same method. Primary rat kidney cells $(\mathrm{RKC})$ were prepared from 5-week-old fernale rats according to Parker's method (16). Rat submaxillary gland cell cultures (SMGC) were also prepared from 5 -week-old female rats by explantation. Mouse brain cells (MBC) were obtained from 15-day-old embryos by dispersion with pipetting. All cell cultures were prepared in Plastic flasks with $25 \mathrm{~cm}^{2}$ growth area and routinely used for virus isolation.

\section{Effect of Cytosine Arabinoside (Ara-C)}

To examine the type of nucleic acid of CARS, monolayers of $3 \mathrm{~T} 3$ cells were infected with CARS or vaceinia virus $\left(10^{3.0} \mathrm{PFU} / 0.2 \mathrm{ml}, \mathrm{MOI}=0.01\right)$. After an adsorption period of 1 hour, cultures were washed twice HBSS, and $5 \mathrm{ml}$ of maintenance medium eontaining various doses of Ara-C was added. After 48 hours at $37^{\circ} \mathrm{C}$, the amount of infectivity was titrated by the plaque assay method using $3 \mathrm{~T} 3$ cells.

\section{Antiserum}

Hyperimmune antiserum against MHV-2 was prepared by giving guinea pigs five intraperitoneal injections with $3 \mathrm{ml}$ of virus fluid at one-week intervals. One week after the last immunization, these animals were bled aseptically by cardiac puncture. Convalescent antisera against SDAV and CARS were made in Slc:SD male rats inoculated intranasally (i.n.) with $0.05 \mathrm{ml}$ of virus fluids containing $10^{2.7}-10^{3.1} \mathrm{MLD}_{50} / \mathrm{ml}$. Blood was collected four weeks after inoculation.

\section{Complement-Fixation Test}

All antisera used for the serological test were inactivated at $56^{\circ} \mathrm{C}$ for 30 minutes prior to use. The complement-fixation (CF) test was carried out employing the modified micro-method of HaLonen et al. (9), i.e., 2 units of complement and 4 units of antigen with overnight fixation at $4^{\circ} \mathrm{C}$. The complement-fixing antigen unit was determined by testing two-fold dilutions of virus fluids in veronal-buffered saline. The highest dilution of antigen giving 75 per cent fixation was considered to contain 1 unit of antigen.

\section{Neutralization (NT) Test}

The serum specimens, four fold-dilutions in HBSS, were mixed with equal volumes of virus (200 PFU/0.2 ml) diluted with PBS containing 1 per cent bovine serum albumin (BSA). After incubation at $37^{\circ} \mathrm{C}$ for 90 minutes, the remaining virus was titrated by the plaque assay method. The reeiprocal of the highest dilution of serum showing 50 per cent reduction of plaque formation was taken as the titer. In the case of SDAV, $200 \mathrm{MLD}_{50} / 0.02 \mathrm{ml}$ of virus was used. After the incubation period, the remaining virus was titrated in ten 2-day-old suckling mice per dilution, and cumulative death was recorded for 14 days. Antibody titer was described as the reciprocal of the highest dilution of serum preventing 50 per cent mouse death.

\section{Experimental Infection in Rats}

Eight-week-old male rats were inoculated i.n. with $0.05 \mathrm{ml}$ of mouse brain passaged virus or cell-passaged virus containing approximately $10^{2.7} \mathrm{MLD}_{50} / 0.02 \mathrm{ml}$. Control rats were inoculated i.n. with the same volume of HBSS without these viruses. These rats were observed daily for the development of neck swelling for 10 days after inoculation and were examined for immune response by NT and CF tests. Histological changes were also observed microscopically. Tissues were fixed in formal saline, and paraffin sections were stained with haematoxylin and eosin.

\section{Results}

\section{Virus Isolation}

Specimens of enlarged submaxillary glands were removed aseptically from five Jcl:SD rats (9 to 10 weeks old) showing neck swelling at the second day 
after onset in an outbreak. The 10 per cent homogenates were prepared separately and clarified by low-speed centrifugation. Each homogenate was inoculated i.e. at approximately $0.02 \mathrm{~m} /$ mouse into groups of ten 2-day-old suckling mice, which were then housed immediately in a vinyl isolator and observed for 14 days. Some of the mice inoculated with the homogenates showed neurological signs within 3 days after inoculation, often with wandering and squeaking, then became very ill and died within a few days, although some survived 4 to 5 days, after the first signs of overt illness. The number of paralyzed mice varied from three to five of the inoculated animals in each sample. No neurological signs were observed in any of the mice inoculated with unaffected submaxillary glands from healthy rats.

Brains of mice showing neural disease were harvested aseptically and prepared as a 10 per cent homogenate with HBSS. Following low-speed centrifugation, the supernatant was used for the next passage. In the second passage, all inoculated mice developed neurological symptoms and died 7 days of inoculation. The third passage was used in a subsequent experiment as mouse brain passaged virus and stored at $-70^{\circ} \mathrm{C}$ until use.

\section{Multiplication of Mouse Brain Passaged Virus in Cell Cultures}

Mouse brain passaged virus suspension $(0.2 \mathrm{ml})$ was inoculated into various cell cultures, i.e., L929, LLCMK 2 , CV-1, HeLa, 3T3, REC, RKC, MEC, CEC, SMGC and MBC. After incubation at $37^{\circ} \mathrm{C}$ for 1 hour, these cultures were washed twice with HBSS and $5 \mathrm{ml}$ of maintenance medium was added. The cultures were observed for periods of 20 to 30 days, with changes of the medium at intervals of 2 to 3 days. In 3 T 3 cell culture only, small foci of multinucleated giant cells were observed on the 14 th to 15 th days following inoculation. This cytopathic effect (CPE) extended gradually in number and size, followed by degeneration of the affected cells in the center of the lesions, and covered approximately 20 per cent of the area in monolayers at 28 days post-infection. The cultures were harvested on the 30 th day after inoculation, and subsequent passages were carried out with the culture fluids after one cycle of freezing and thawing. The virus suspensions were stored at $-70^{\circ} \mathrm{C}$ and used in these experiments as CARS, unless otherwise mentioned. No CPE was observed in any of the other cell cultures. Additional studies were made to determined whether SDAV produces CPE on the cell cultures as described above; however, there was no noticeable change in the cell cultures tested during 30 days observation.

\section{Effect of $p H$}

The stability of CARS against $\mathrm{pH}$ was tested. Sendai virus was also tested under similar experimental conditions as a standard representing acid-labile virus. Table 1 gives the results. CARS showed $4.5 \times 10^{4}$ and $1.3 \times 10^{4}$ PFU/0.2 ml after treatment at $\mathrm{pH} 7.0$ and 3.0 , respectively, whereas infectivity of Sendai virus was markedly reduced at $\mathrm{pH} 3.0$ treatment compared with that at $\mathrm{pH} 7.0$. Thus, when compared to Sendai virus, CARS is relatively stable at pH 3.0. 
Table 1. Acid stability of the causative agent of rat sialoadenitis (CARS)

\begin{tabular}{llc}
\hline & \multicolumn{2}{c}{ Virus titer $(\mathrm{PFU} / 0.2 \mathrm{ml})$} \\
\cline { 2 - 3 } Treatment & CARS & Sendai virusa \\
\hline Original & $5.6 \times 10^{4}$ & $2.4 \times 10^{7}$ \\
pH 7.0 & $4.5 \times 10^{4}$ & $6.0 \times 10^{6}$ \\
pH 3.0 & $1.3 \times 10^{\mathrm{c}}$ & $2.9 \times 10^{2}$ \\
\hline
\end{tabular}

a Sendai virus was titrated with $\mathrm{LLCMK}_{2}$ cell cultures (18)

b Dialyzed against phosphate buffer for 3 hours at $4^{\circ} \mathrm{C}$

c Dialyzed against acidic buffer (0.05 M tris-(hydroxymethyl) aminomethane and $0.02 \mathrm{M} \mathrm{HCl}$ ) for 3 hours at $4^{\circ} \mathrm{C}$

\section{Sensitivity of Lipid Solvent}

The effect of lipid solvent on the infectivity of CARS was examined with respect to 20 per cent ether (1) and chloroform (8). Sendai virus and poliovirus were used as references for a sensitive and a resistant control, respectively. Results are given in Table 2. The infectivity of Sendai virus and CARS was markedly reduced by treatment of ether and chloroform, while poliovirus was resistant under the same condition.

\section{Effect of Temperature on Infectivity}

Virus suspensions in PBS with or without 1 per cent BSA were incubated at $37^{\circ} \mathrm{C}$ for 180 minutes. The infectivity was titrated at intervals by the plaque assay method. When PBS was used as a diluent, CARS infectivity decreased by about 90 per cent with a treatment time of 60 to 180 minutes, while there was little loss of infectivity in PBS containing 1 per cent BSA. When the test was done at $56^{\circ} \mathrm{C}$, however, there was a rapid loss of infectivity within 5 minutes in both diluents.

\section{Effect of Ara-C on the Multiplication of CARS}

Monolayers of $3 \mathrm{~T} 3$ cells were infected with either CARS or vaccinia virus and treated with 3 and $30 \mu \mathrm{g} / \mathrm{ml}$ of Ara-C. The infected cells without the treatment served as a control. After 48 hours incubation at $37^{\circ} \mathrm{C}$, the cultures were harvested and titrated for viral growth. The result is presented in Table 3.

Multiplication of CARS was not inhibited by the treatment with DNA inhibitor, while that of vaccinia virus, a DNA-containing virus, was clearly

Table 2. Sensitivity of CARS to lipid solvent

\begin{tabular}{llll}
\hline & \multicolumn{3}{c}{ Virus titer (PFU/0.2 ml) } \\
\cline { 2 - 4 } Lipid solvent & CARS & Poliovirus & Sendai virus \\
\hline Control & $1.5 \times 10^{3}$ & $1.2 \times 10^{7}$ & $1.8 \times 10^{8}$ \\
Ether & $1.0 \times 10^{0}$ & $1.1 \times 10^{7}$ & - \\
Chloroform & $1.0 \times 10^{0}$ & $9.0 \times 10^{6}$ & $1.0 \times 10^{1}$ \\
\hline
\end{tabular}

a Poliovirus was titrated with HeLa cell cultures 
Table 3. Effect of cytosine arabinoside (Ara-O) on wiral growth of OARS

Cone. of Ara-C

$(\mu \mathrm{g} / \mathrm{ml})$

Control

30

3

Virus titer (PFU/0.2 ml) after 48 hours at $37^{\circ} \mathrm{C}$

\begin{tabular}{ll}
\hline CARS & Vaccinia virus \\
$2.0 \times 10^{3}$ & $1.8 \times 10^{6}$ \\
$1.1 \times 10^{3}$ & $3.2 \times 10^{3}$ \\
$8.6 \times 10^{2}$ & $7.5 \times 10^{3}$ \\
\hline
\end{tabular}

reduced by the inhibitor. This result suggests that the nucleic acid type of CARS is RNA.

\section{Electron Microscopic Observation}

Monolayers of $3 \mathrm{~T} 3$ cells infected with CARS were harvested, then subjected to three cycles of freezing and thawing. After centrifugation at $20,000 \mathrm{rpm}$ for 120 minutes, the pellet obtained used for negative contrast staining. The specimen was examined with a JEM-100B ultramicroscope.

Although some viral particles had no projections as the CARS projections were very fragile, there were typical particles in morphology as was observed in the coronavirus group $(2,7,14,15)$. Measurement of the particle size indicated an approximate diameter of $100 \mathrm{~nm}(85-125 \mathrm{~nm})$.

\section{Serological Studies}

As shown in Table 4, in the CF test, there was two-way cross reaction between SDAV and CARS. However, no cross reaction was observed between MHV -2 and SDAV, while CARS shared some antigens with MHV-2.

On the other hand, in the NT test, although there was two-way cross reaction between SDAV and CARS, each virus was neutralized by at least an 8-fold greater dilution of homologous antiserum than heterologous antiserum. In addition, the neutralization test was performed to clarify a serological relationship between these two viruses using 20 units of antiserum. The result is shown in Table 5. Each of SDAV and CARS was neutralized completely by 20 units of homologous antiserum, while the same units of heterologous antiserum did not have enough titer to neutralize each of the viruses.

Table 4. Serological relationship between SDAV, MHV-2, and CARS

\begin{tabular}{llrrr}
\hline & & \multicolumn{3}{c}{ Antiserum } \\
\cline { 3 - 5 } Test & Antigen & CARS & SDAV & MHV-2 \\
\hline CF $^{\mathrm{a}}$ & CARS & 64 & 32 & 32 \\
& SDAV & 16 & 64 & $<8$ \\
& MHV-2 & 8 & $<8$ & 64 \\
$\mathrm{NT}^{\mathrm{b}}$ & CARS & 8192 & 1024 & $<16$ \\
& SDAV & 256 & 8192 & $<16$ \\
& MHV -2 & $<16$ & $<16$ & 4096 \\
\hline
\end{tabular}

a Complement-fixation test

v Neutralization test 
Table 5. Cross neutralization between $S D A V$ and CARS by their antisera containing 20 units of antibody

\begin{tabular}{|c|c|c|c|}
\hline \multirow[b]{2}{*}{ Antigen } & \multicolumn{2}{|c|}{ Antiserum } & \multirow[b]{2}{*}{ Control } \\
\hline & CARS & SDAV & \\
\hline CARS (200 PFU) & $0^{\mathrm{a}} \quad(100 \%)^{\mathrm{c}}$ & $31^{\mathrm{a}} \quad(80 \%)$ & $155^{\mathrm{a}}$ \\
\hline SDAV (200 MLD 50$)$ & $2 / 10^{b} \quad(20 \%)$ & $10 / 10^{b}(100 \%)$ & $0 / 10^{\mathrm{b}}$ \\
\hline
\end{tabular}

a Number of plaques

b Number of mice surviving / Number of mice tested

c Number in parentheses showed percentage of neutralization. SDAV and CARS were diluted to contain $200 \mathrm{MLD}_{50} / 0.02 \mathrm{ml}$ and $200 \mathrm{PFU} / 0.2 \mathrm{ml}$, respectively. Antiserum was diluted to produce 20 units of the NT titer and mixed with virus to be tested as shown in Table 5. Mixture of CARS and antiserum was inoculated into $3 \mathrm{~T} 3$ cells, and mixture of SDAV and antiserum was inoculated i.c. into 2-dayold suckling mice

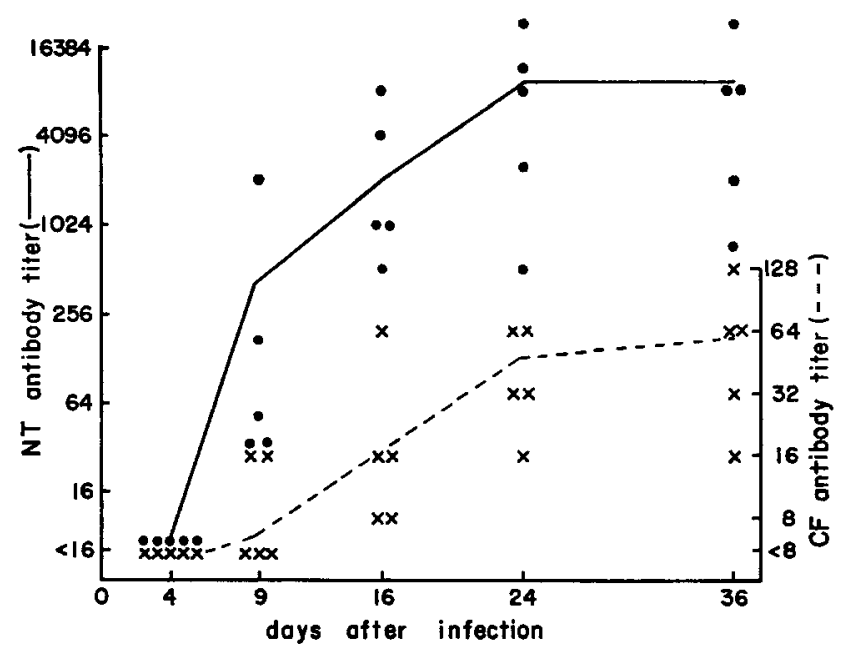

Fig. 1. Development of neutralizing (NT) and complement-fixing (CF) antibody titers of rat sera infected with cell-passaged virus of CARS $\left(10^{2.7} \mathrm{MLD}_{50} / 0.05 \mathrm{ml} / \mathrm{rat}\right)$. Symbols •, $\mathrm{x}$ represent each antibody titer of the NT and CF from a single sample, respectively

\section{Experimental Infection in Rats}

CARS was apparently pathogenic for rats. When 8 -week-old rats were inoculated i.n. with mouse brain passaged virus, 94 per cent of the infected animals developed signs of illness (Table 6), which was characterized by swelling of the neck by 4 to 5 days after inoculation. In some cases, ophthalmic lesions, with the appearance of red tears round the eyelids and swelling of the eyelids, appeared later at 6 to 7 days post-inoculation. The animals recovered within about 10 days after inoculation and there were no deaths. The antibody titers of sera from five rats infected with cell-passaged virus were detected on day 9, and increased up to day 24 in both NT and CF antibodies (Fig. 1). Similar results were also obtained in mouse brain passaged virus injected rats (data not shown). 
Sera of uninfected control rats remained negative in the period tested. When the rats were examined 5 days after inoculation, gelatinous periglandular oedema was observed and involved the area from the neck to the chest in all affected animals.

Both enlarged submaxillary glands were removed and a 10 per cent homogenate was prepared from each pair. Two-day-old mice were inoculated i.c. with the homogenate and typical paralytic disease was observed in all animals. The virus was recoverable, i.e., CARS was isolated in $3 \mathrm{~T} 3$ cell cultures from the homogenates of the brains removed from the affected mice.

Microscopically, oedema and inflammatory cell infiltration were marked in periglandular and intralobular connective tissues of the submaxillary gland. In the parenchyma of the gland, especially in the epithelium of the striated portion, obvious necrotic degeneration was observed. Similar slight degeneration was also observed in the epithelium of the secreting part and the duct of the gland. Inflammatory cell infiltration and vacuolated cells were also detected in the lamina propria and tela submucosa of the upper respiratory tract, although the lower tract was unaffected. These histological changes were very similar to those observed during the natural outbreak.

Passage of CARS has been performed in $3 \mathrm{~T} 3$ cell culture up to 35 passages. The 1 st, 4 th, 7 th, 25 th and 35 th passage viruses in a series were used for experimental infections as shown in Table 6. Although the virulence of mouse brain passaged virus in rats decreased during the cell passages, the 35 th passage of the virus was still pathogenic for rats, and enlargement of the submaxillary gland was of almost the same intensity as in rats infected with virus passaged in mouse brain. Mouse brain adapted SDAV containing about $10^{3,1} \mathrm{MLD}_{50} / 0.02 \mathrm{ml}$ was also inoculated i.n. into five 8-week-old rats, however, there were no signs of sialodacryoadenitis during the 20 days after inoculation. All five rats had developed high levels of NT antibody $(1: 2048-1: 8192)$ in their sera at this time.

\section{Diseussion}

Evidence described in this report demonstrated that CARS is a member of coronavirus group $(15,19)$. Although all murine coronaviruses can replicate in the brain of suckling mice, the viruses are fastidious about their cultural re-

Table 6 . Virulence for rats of the CARS in cell passage

\begin{tabular}{llc}
\hline \multirow{2}{*}{$\begin{array}{l}\text { Serial passage number } \\
\text { in } 3 \text { T } 3 \text { cells }\end{array}$} & \multicolumn{2}{c}{ Detection of neck swelling } \\
\cline { 2 - 3 } & Infected & Control \\
\hline $0^{\mathrm{a}}$ & $17 / 18^{\mathrm{b}}$ & $0 / 18$ \\
1 & $1 / 6$ & $0 / 6$ \\
4 & $3 / 6$ & $0 / 6$ \\
7 & $2 / 6$ & $0 / 6$ \\
$\mathbf{1 5}$ & $0 / 6$ & $0 / 6$ \\
35 & $2 / 6$ & $0 / 6$ \\
\hline
\end{tabular}

a Mouse brain passaged virus

b Number of positive rats / Number of tested rats 
quirements, i.e., their replication is generally species-specific and occurs only in cell eultures of the host species $(15,16,19)$. The in vitro propagation of SDAV has been possible only in primary rat kidney cells (3). When SDAV was infeeted on $3 \mathrm{~T} 3$ cells, there was no appreciable CPE during 30 days observation. CARS, however, could replicate in mouse-derived $3 \mathrm{~T} 3$ cells, which differ from the species of origin, with multinucleated giant cells formation.

BHATT et al. (3) recognized that there was cross-reaction between MHV and SDAV in the CF test, and SDAV possessed some antigens shared with MHV in the NT, using polyvalent antiserum, in addition, SDAV and rat coronavirus (RCV) are closely related viruses although there is a slight difference in cross NT test. In the present experiment however, when monovalent antiserum was used, there was no cross-reaction between SDAV and MHV-2 in the CF test, while CARS possessed some antigens shared with MHV-2. Both SDAV and CARS, however, clearly differed from MHV-2 in the N'T test with monovalent antisera. (Table 4). These data suggest that serological tests with monovalent antisera may have a more type-specific reaction than those with polyvalent antisera. Similar results have also observed among MHV strains $(6,10)$, i.e., clear serological differences have been observed among MHV strains and other mammalian coronaviruses in NT test with monovalent antisera.

SDAV and CARS may be regarded as serological variants derived from a single serotype with respect to the results of the CF test in which no cross reaction between SDAV and MHV-2 was observed, although they belong to the homologous serotype at least with regard to the result of the NT test. The results obtained in this experiment suggest that there are different serotypes in the rat-coronavirus group as was observed in MHV group $(6,10)$. However, further work using NT and $\mathrm{CF}$ tests with monovalent antisera needs to be undertaken in order to demonstrate significant antigenic differences between SDAV, RCV, CARS and other isolates.

SDAV appeared to lose its virulence for susceptible rats during passage (at the 4 th passage level) in the brain of infant mice (3), but no change in virulence was observed during passage (at the 8 th passage level) in submaxillary glands of rats (13). RCV was also asymtomatic in adult rats $(5,16)$. In contrast with SDAV and RCV, CARS showed no change in virulence for susceptible rats after three serial passages in the brains of suckling mice, although cell passage virus became somewhat attenuated with such treatment (Table 6).

SDAV evoked both NT and CF antibody responses when inoculated i.n. in mice (4). We also examined whether CARS is infectious for mice (data not shown), and found that it was possible to infect three-week-old mice i.n. with $10^{2.7} \mathrm{MLD}_{50}$ of CARS. These asymptomatic animals developed NT antibody to CARS in their sera. In view of this observation it would be of interest to determine whether rat coronavirus is also a naturally occurring infection of mice.

\section{Acknowledgments}

The authors are indebted to K. Imai of the Hatano Research Institute, Food and Drug Safety Center, Kanagawa, Japan, for his helpful suggestions in the histological studies, and Jinrin Sasaki of the School of Medicine, University of Akita, Akita, Japan, for the electron microscopic study. 


\section{References}

1. Andrews, C. H., Honstmand, D. M.: The susceptibility of viruses to ethyl ether. J. gen. Microbiol. 3, 290-297 (1949).

2. Berry, D. M., Crutcrshank, J. G., Chu, H. P., Wells, R. J. H.: The structure of infectious bronchitis virus. Virology 23, 403-407 (1964).

3. Bhatt, P. N., Percx, D. H., Jonas, A. M.: Characterization of the virus of sialodacryoadenitis of rats; a member of the coronavirus group. J. Infect. Dis. 126, $123-130$ (1972).

4. Bhatt, P. N., JaCOBY, R. O., Jonas, A. M.: Respiratory infection in mice with sialodacryoadenitis virus, a coronavirus of rats. Infect. Immunol. 18, 823-827 (1977).

5. Bhatт, P. N., JACOBY, R. O.: Experimental infection of adult axenic rats with Parker's rat coronavirus. Arch. Virol. 54, 345-352 (1977).

6. Bradburne, A. F.: Antigenic relationship amongst coronaviruses. Arch. ges. Virusforsch. 31, 365-372 (1970).

7. Bridger, J. C., Caul, E. O., EgGlastone, S. I.: Replication of an enteric bovine coronavirus in intestinal organ cultures. Arch. Virol. 57, $43-51$ (1978).

8. Feldman, H. A., Wane, S. S.: Sensitivity of various viruses to chloroform. Proe. Soc. Exp. Biol. Med. 106, 736-738 (1961).

9. Halonen, P., Hugbarer, R. J., Turner, H. C.: Preparation of ECHO complementfixing antigens in monkey kidney tissue culture and their purification by fluorocarbon. Proc. Soc. Exp. Biol. Med. 97, 530-535 (1958).

10. Hterholzer, J. C., Broderson, J. R., Murphy, F. A.: New strain of mouse hepatitis virus as the cause of lethal enteritis in infant mice. Infect. Immunol. 24, $508-522(1979)$.

11. Inses, J. R. M., Stanton, M. F. : Acute disease of the submaxillary and harderian glands (sialo-dacryoadenitis) of rats with cytomegaly and no inclusion bodies. Am. J. Path. 38, 455-468 (1961).

12. Ishida, T., Taguchi, F., Lee, Y.-S., Yamada, A., Tamura, T., Fujiwara, K.: Isolation of mouse hepatitis virus from infant mice with fatal diarrhea. Lab. Anim. Sei. 28, $269-276(1978)$.

13. Jacoby, R. O., Bhatr, P. N., Jonas, A. M.: Pathogenesis of sialodacryoadenitis in gnotobiotic rats. Vet. Pathol. 12, 196-209 (1975).

14. Kojlma, A., Fujnami, F., Dor, K., Yasoshma, A., OKaniwa, A.: Isolation and properties of sialodacryoadenitis virus of rats. Exp. Anim. 29, 401-418 (1980).

15. MoIntosh, K.: Coronaviruses: a comparative review. Curr. Top. Microbiol. Immunol, 63, 85-129 (1974).

16. Parker, J. C., Cross, S. S., Rowe, W. P.: Rat coronavirus (RCV): a prevelent, naturally occurring pneumotropic virus of rats. Arch. ges. Virusforseh. 31, 293$302(1970)$.

17. Rowe, W. P., Hartuex, J. W., Capps, W. I.: Mouse hepatitis virus infection as a highly contagious, prevalent enteric infection of mice. Proc. Soc. Exp. Biol. Med. 112, 161-165 (1963).

18. SugtTa, K., Maru, M., Sato, K.: A sensitive plaque assay for sendai virus in an established line of monkey cells. Japan. J. Microbiol. 18, 262-264 (1974).

19. Tyrreli, D. A. J., Axexander, D. J., Armeida, J. D., Cunningham, C. H., Easterday, B. C., Garwes, D. J., Hterholzer, J. C., Kapikran, A., MacNaUghton, M. R., McIntosh, K.: Coronaviridae: second report. Intervirol. 10, $321-328(1978)$.

20. Ursumi, K., Maeda, T., Tatsumt, H., Fujiwara, K.: Some elinical and epizootological observations of infectious sialoadenitis in rats. Exp. Anim. 27, 283287 (1978). 
21. Virelizier, J. L., Dayan, A. D., Alison, A. C.: Neuropathologieal effects of persistent infection of mice by mouse hepatitis virus. Infect. Immun. 12, 11271140 (1975).

22. WARd, J. M., Collins, M. J., PARker, J. C.: Naturally occurring mouse hepatitis virus infection in the nude mouse. Lab. Anim. Sci. 27, 372-376 (1977).

23. Weisbroth, S. H., Peress, N.: Ophthalmic lesions and dacryoadenitis: a naturally occurring aspect of sialodacryoadenitis virus infection of the laboratory rat. Lab. Anim. Sci. 27, 466-473 (1977).

Authors' address: Dr. K. SAto, Shionogi Research Laboratories, Shionogi \& Co., Ltd. Fukushima-ku, Osaka, 553 Japan.

Received January 4, 1982 